\title{
Role of the Phosphine Ligands on the Stabilization of Monoadducts of the Model Nucleobases 1-Methylcytosine and 9-Methylguanine in Platinum(II) Complexes
}

\author{
Diego Montagner ${ }^{\dagger}$ Ennio Zangrando, ${ }^{\ddagger}$ and Bruno Longato ${ }^{\star, \dagger}$ \\ Dipartimento di Scienze Chimiche, Universitá di Padova, Via Marzolo 1, 35131 Padova, Italy, \\ and Dipartimento di Scienze Chimiche, Universitá di Trieste, Via Giorgieri 1, 34127 Trieste, Italy
}

Received October 13, 2007

\begin{abstract}
The addition of 1-methylcytosine (1-MeCy) or 9-methylguanine (9-MeGu) to solutions of cis- $\left(\mathrm{PPh}_{3}\right)_{2} \mathrm{Pt}\left(\mathrm{ONO}_{2}\right)_{2}(1 \mathrm{a})$, in a molar ratio of 1:1, affords the monoadducts cis-[( $\left.\left.\mathrm{PPh}_{3}\right)_{2} \mathrm{Pt}(1-\mathrm{MeCy})\left(\mathrm{ONO}_{2}\right)\right] \mathrm{NO}_{3}(2 \mathrm{a})$ and cis-[(PPh$)_{2} \mathrm{Pt}(9-$ $\left.\mathrm{MeGu})\left(\mathrm{ONO}_{2}\right)\right] \mathrm{NO}_{3}(3 \mathrm{a})$ and only trace amounts of the bisadducts cis-[( $\left.\left.\mathrm{PPh}_{3}\right)_{2} \mathrm{Pt}(1-\mathrm{MeCy})_{2}\right]\left(\mathrm{NO}_{3}\right)_{2}(4 \mathrm{a})$ and cis$\left[\left(\mathrm{PPh}_{3}\right)_{2} \mathrm{Pt}(9-\mathrm{MeGu})_{2}\right]\left(\mathrm{NO}_{3}\right)_{2}(5 \mathrm{a})$, respectively. The $\mathrm{X}$-ray structural determination of $\mathbf{2 a}$ and $3 \mathbf{a}$ indicates a strong $\pi-\pi$ stacking interaction between one of the $\mathrm{PPh}_{3}$ phenyl groups and the pyrimydinic N3-platinated cytosine or the imidazole part of the N7-coordinated guanine base. The addition of a further equiv of nucleobase to the monoadducts forms quantitatively the bisadducts that have been isolated as pure compounds $\mathbf{4 a}$ and $\mathbf{5 a}$. Under the same experimental conditions, the dinitrato analogue cis-[( $\left.\left.\mathrm{PMePh}_{2}\right)_{2} \mathrm{Pt}\left(\mathrm{ONO}_{2}\right)_{2}\right](1 \mathbf{b})$ forms the monoadducts $\mathbf{2 b}$ and $\mathbf{3 b}$ in equilibrium with a relatively high concentration $(20-30 \%)$ of the bisadducts cis-[( $\left.\mathrm{PMePh}_{2}\right)_{2} \mathrm{Pt}(1-$ $\left.\mathrm{MeCy})_{2}\right]\left(\mathrm{NO}_{3}\right)_{2}(\mathbf{4} \mathbf{b})$ and cis-[(PMePh$\left.\left.)_{2}\right)_{2} \mathrm{Pt}(9-\mathrm{MeGu})_{2}\right]\left(\mathrm{NO}_{3}\right)_{2}(\mathbf{5} \mathbf{b})$, which have been structurally characterized by single-crystal X-ray analysis. The characterization of the isolated complexes by multinuclear NMR spectroscopy is also described.
\end{abstract}

\section{Introduction}

In the last 40 years, the interactions of model nucleobases with metal ions have been studied in great detail, in particular toward $\mathrm{Pt}^{\mathrm{II}}$ centers having amine or diamine as ancillary ligands. ${ }^{1}$ Recently, we have demonstrated that the use of monodentate phosphines $\left(\mathrm{PR}_{3}\right)$ as ligands led to the formation of platinum(II) complexes in which the nuclearity of the adducts and/or the binding mode of the nucleobase appear to depend on the nature of the substituents $\mathrm{R}$ on the phosphorus atoms. For instance, deprotonation of 9-substituted adenine (9-MeAd) promoted by the hydroxo complexes cis- $\left[\mathrm{L}_{2} \mathrm{Pt}(\mu-\mathrm{OH})\right]_{2}\left(\mathrm{NO}_{3}\right)_{2}$ affords the dinuclear species cis$\left[\mathrm{L}_{2} \mathrm{Pt}\left\{9-\mathrm{MeAd}(-\mathrm{H})-N^{1} N^{6}\right\}\right]_{2}\left(\mathrm{NO}_{3}\right)_{2}$ when $\mathrm{L}$ is $\mathrm{PMe}_{3}{ }^{2}$ and the trinuclear adducts $c i s-\left[\mathrm{L}_{2} \mathrm{Pt}\left\{9-\mathrm{MeAd}(-\mathrm{H})-N^{1} N^{6}\right\}\right]_{3}\left(\mathrm{NO}_{3}\right)_{3}$ when

* To whom correspondence should be addressed. E-mail: bruno.longato@ unipd.it.

Universitá di Padova.

$\div$ Universitá di Trieste.

(1) Lippert, B.; Müller, J. Concepts and Models in Bioinorganic Chemistry; Kraatz, H.-B., Metzler-Nolte, N., Eds.; Wileys-VCH: Weinheim, Germany, 2006; p 137.

(2) Schenetti, L.; Mucci, A.; Longato, B. J. Chem. Soc., Dalton Trans. 1996, 299.
$\mathrm{L}$ is $\mathrm{PMe}_{2} \mathrm{Ph}$ and $\mathrm{PMePh}_{2},{ }^{3}$ whereas the mononuclear species cis-[ $\left[\mathrm{L}_{2} \mathrm{Pt}\left\{9-\mathrm{MeAd}(-\mathrm{H})-N^{6} N^{7}\right\}\right] \mathrm{NO}_{3}$ is formed when $\mathrm{L}$ is $\mathrm{PPh}_{3}{ }^{4}$ Similarly, deprotonation of 1-methylcytosine (1$\mathrm{MeCy})$ leads to the polynuclear adducts $c i s-\left[\mathrm{L}_{2} \mathrm{Pt}\{1-\mathrm{MeCy}-\right.$ $\left.\left.(-\mathrm{H})-N^{3} N^{4}\right\}\right]_{3}\left(\mathrm{NO}_{3}\right)_{3}$ with the less hindered phosphines $\mathrm{PMe}_{3}{ }^{5}$ and $\mathrm{PMe}_{2} \mathrm{Ph},{ }^{6}$ while the mononuclear species cis- $\left[\mathrm{L}_{2} \mathrm{Pt}\{1-\right.$ $\left.\left.\mathrm{MeCy}(-\mathrm{H})-N^{4}\right\}\left(1-\mathrm{MeCy}-N^{3}\right)\right]\left(\mathrm{NO}_{3}\right)$ is quantitatively obtained when $\mathrm{L}$ is $\mathrm{PPh}_{3}{ }^{6}$

In this paper, we report the synthesis and characterization of the complexes cis-[(PPh $)_{2} \mathrm{Pt}$ (nucleobase $\left.)\left(\mathrm{ONO}_{2}\right)\right] \mathrm{NO}_{3}$ and cis- $\left[\left(\mathrm{PPh}_{3}\right)_{2} \mathrm{Pt}(\text { nucleobase })_{2}\right]\left(\mathrm{NO}_{3}\right)_{2}$, containing the neutral nucleobases 1-MeCy and 9-methylguanine (9-MeGu) acting as monodentate ligands. Early studies have shown that the nitrato complexes cis- $\mathrm{L}_{2} \mathrm{Pt}\left(\mathrm{ONO}_{2}\right)_{2}$, obtained from the cis-

(3) (a) Longato, B.; Pasquato, L.; Mucci, A.; Schenetti, L. Eur. J. Inorg. Chem. 2003, 128. (b) Longato, B.; Pasquato, L.; Mucci, A.; Schenetti, L.; Zangrando, E. Inorg. Chem. 2003, 42, 7861.

(4) Montagner, D.; Longato, B. Inorg. Chim. Acta, 2007, doi: 10.1016/ j.ica.2007.02.025.

(5) Trovò, G.; Bandoli, G.; Casellato, U.; Corain, B.; Nicolini, M.; Longato, B. Inorg. Chem. 1990, 29, 4616.

(6) Longato, B.; Montagner, D.; Zangrando, E. Inorg. Chem. 2006, 45, 8179 . 
platin analogues cis- $\mathrm{L}_{2} \mathrm{PtCl}_{2}$ ( $\mathrm{L}=$ tertiary phosphines), in reactions with 1 equiv of these nucleobases, form mixtures of $c i s-\left[\mathrm{L}_{2} \mathrm{Pt}(\text { nucleobase })\right]^{2+}$ and $c i s-\left[\mathrm{L}_{2} \mathrm{Pt}(\text { nucleobase })_{2}\right]^{2+}$, in equilibrium with the unreacted starting nitrate. The relatively high stability of the bisadducts precludes the isolation of the intermediate species cis- $\left[\mathrm{L}_{2} \mathrm{Pt}\right.$ (nucleobase $\left.)\right]^{2+}{ }^{3}$ However, the presence of $\mathrm{PPh}_{3}$ ligands stabilizes enough such intermediates to allow their isolation as pure compounds. The single-crystal $\mathrm{X}$-ray analyses of $c i s-\left[\left(\mathrm{PPh}_{3}\right)_{2} \mathrm{Pt}(1-\mathrm{MeCy})\left(\mathrm{ONO}_{2}\right)\right]^{+}$and $c i s-$ $\left[\left(\mathrm{PPh}_{3}\right)_{2} \mathrm{Pt}(9-\mathrm{MeGu})\left(\mathrm{ONO}_{2}\right)\right]^{+}$are reported here along with a study of their behavior in solution by NMR spectroscopy. With the less hindered phosphine $\mathrm{PMePh}_{2}$, we were able to isolate only the bisadducts $c i s-\left[\left(\mathrm{PMePh}_{2}\right)_{2} \mathrm{Pt}(1-\mathrm{MeCy})_{2}\right]^{2+}$ and cis- $\left[\left(\mathrm{PMePh}_{2}\right)_{2} \mathrm{Pt}(1-\mathrm{MeCy})_{2}\right]^{2+}$, whose $\mathrm{X}$-ray structures are also described. Finally, the relative stabilities of the monoadducts cis- $\left[\mathrm{L}_{2} \mathrm{Pt}(\text { nucleobase })\right]^{2+}\left(\mathrm{L}=\mathrm{PMePh}_{2}, \mathrm{PPh}_{3}\right)$ have been evaluated.

\section{Experimental Section}

Instrumentation and Materials. NMR spectra of various solvents at $300 \mathrm{~K}$ were obtained in solution in 5-mm sample tubes for ${ }^{1} \mathrm{H},{ }^{31} \mathrm{P}$, and ${ }^{195} \mathrm{Pt}$ (operating at $300.13,121.5$, and $64.2 \mathrm{MHz}$, respectively) with a Bruker AVANCE $300 \mathrm{MHz}$ spectrometer equipped with a variable-temperature apparatus and for ${ }^{15} \mathrm{~N}$ (operating at $40.6 \mathrm{MHz}$ ) with a Bruker $400 \mathrm{AMX}-\mathrm{WB}$ spectrometer. The ${ }^{1} \mathrm{H}$ NMR chemical shifts were referenced to the residual impurity of the solvent. The external references were $\mathrm{H}_{3} \mathrm{PO}_{4}(85 \%$ w/w in $\mathrm{D}_{2} \mathrm{O}$ ) for ${ }^{31} \mathrm{P}, \mathrm{Na}_{2} \mathrm{PtCl}_{4}$ in $\mathrm{D}_{2} \mathrm{O}$ (adjusted to $\delta=-1628$ ppm from $\mathrm{Na}_{2} \mathrm{PtCl}_{6}$ ) for ${ }^{195} \mathrm{Pt}$, and $\mathrm{CH}_{3} \mathrm{NO}_{2}$ (in $\mathrm{CDCl}_{3}$ at $50 \%$ w/w) for ${ }^{15} \mathrm{~N}$. Inverse-detected spectra were obtained through heteronuclear multiple-bond (HMBC) correlation experiments, using parameters similar to those previously reported. ${ }^{2}$

The solvents $\mathrm{CDCl}_{3}, \mathrm{DMSO}-d_{6}, \mathrm{DMF}-d_{7}$, and $\mathrm{CD}_{2} \mathrm{Cl}_{2}$ and the reagent $9-\mathrm{MeGu}$ (Aldrich) were used as received unless otherwise stated. cis- $\left(\mathrm{PPh}_{3}\right)_{2} \mathrm{PtCl}_{2},{ }^{7}$ cis- $\left(\mathrm{PMePh}_{2}\right)_{2} \mathrm{Pt}\left(\mathrm{ONO}_{2}\right)_{2} \quad$ (1b), ${ }^{3}$ cis$\left(\mathrm{PMe}_{3}\right)_{2} \mathrm{Pt}\left(\mathrm{NO}_{3}\right)_{2},{ }^{5}$ and $1-\mathrm{MeCy}^{8}$ were synthetized as previously reported. cis- $\left(\mathrm{PPh}_{3}\right)_{2} \mathrm{Pt}\left(\mathrm{ONO}_{2}\right)_{2}$ (1a), recently described by us, ${ }^{4}$ crystallized from dimethylformamide (DMF) in the presence of diethyl ether vapors, gave crystals having the composition $\mathbf{1 a} \cdot \mathrm{DMF}$, as shown by ${ }^{1} \mathrm{H}$ NMR and elemental analysis. Elem anal. Calcd for $\mathrm{C}_{39} \mathrm{H}_{37} \mathrm{~N}_{3} \mathrm{O}_{7} \mathrm{P}_{2} \mathrm{Pt}$ : C, 51.09; H, 4.07; N, 4.58. Found: C, 51.21; $\mathrm{H}, 3.93 ; \mathrm{N}, 4.27$. $\mathrm{A} \mathrm{CHCl}_{3}$ solution of $\mathbf{1 a}$, allowed to concentrate at room temperature, released crystals appropriate for $\mathrm{X}$-ray analysis, having the composition cis- $\left(\mathrm{PPh}_{3}\right)_{2} \mathrm{Pt}\left(\mathrm{ONO}_{2}\right)_{2} \cdot \mathrm{CHCl}_{3}$.

Preparation of the Complexes. Synthesis of cis-[(PPh$)_{2} \mathbf{P t}$ $\left.(\mathbf{1 - M e C y})\left(\mathrm{ONO}_{2}\right)\right]\left(\mathbf{N O}_{3}\right)$ (2a). To a solution of 1a $\cdot \mathrm{DMF}(73.4 \mathrm{mg}$, $0.08 \mathrm{mmol})$ in DMF (3 mL) was added $10.2 \mathrm{mg}$ of $1-\mathrm{MeCy}(0.08$ $\mathrm{mmol}$ ), under stirring at room temperature, obtaining a solution in ca. $10 \mathrm{~min}$. The addition of $\mathrm{Et}_{2} \mathrm{O}(10 \mathrm{~mL})$ afforded a white precipitate, which was recovered by filtration and dried under vacuum. The yield of a solid, having the composition cis$\left(\mathrm{PPh}_{3}\right)_{2} \mathrm{Pt}(1-\mathrm{MeCy})\left(\mathrm{NO}_{3}\right)_{2} \cdot \mathrm{DMF}$, was $55 \mathrm{mg}(66 \%)$. Elem anal. Calcd for $\mathrm{C}_{44} \mathrm{H}_{44} \mathrm{~N}_{6} \mathrm{O}_{8} \mathrm{P}_{2} \mathrm{Pt}$ : C, 50.72; H, 4.26; N, 8.07. Found: $\mathrm{C}$, 49.76; H, 4.14; N: 8.08. ${ }^{1} \mathrm{H}$ NMR in DMSO- $d_{6}(\delta): 8.72$ (br s, $1 \mathrm{H}$, $\mathrm{NH}_{2}$ ), 8.08 (br s, $1 \mathrm{H}, \mathrm{NH}_{2}$ ), 7.60-7.35 (c m, 31H, $\mathrm{PPh}_{3}$ and $\mathrm{H} 6$ ), 5.60 and $5.45\left[\mathrm{~d},{ }^{3} J_{\mathrm{HH}}=7.1 \mathrm{~Hz} \mathrm{H} 5\right], 2.91$ and $3.08\left(\mathrm{~s}, 3 \mathrm{H}, \mathrm{NCH}_{3}\right)$. DMF resonances: $7.94(\mathrm{~s}, 1 \mathrm{H}, \mathrm{CHO}), 2.88\left(\mathrm{~s}, 3 \mathrm{H}, \mathrm{CH}_{3}\right), 2.72(\mathrm{~s}$, $\left.3 \mathrm{H}, \mathrm{CH}_{3}\right) .{ }^{31} \mathrm{P}\left\{{ }^{1} \mathrm{H}\right\}$ NMR in DMSO- $d_{6}(\delta)$ : two AB multiplets at

(7) Chock, P. B.; Halpern, J.; Paulick, F. E. Inorg. Synth. 1973, 14, 90.

(8) Kistenmacher, T. J.; Rossi, M.; Caradonna, J. P.; Marzilli, L. G. Adv. Mol. Relax. Interact. Processes 1979, 15, 119. $5.36\left(\mathrm{~d},{ }^{2} J_{\mathrm{PP}}=22.6 \mathrm{~Hz},{ }^{1} J_{\mathrm{PPt}}=4080 \mathrm{~Hz}\right), 5.12\left(\mathrm{~d},{ }^{2} J_{\mathrm{PP}}=22.6 \mathrm{~Hz}\right.$, $\left.{ }^{1} J_{\mathrm{PPt}}=3536 \mathrm{~Hz}\right), 4.60\left(\mathrm{~d},{ }^{2} J_{\mathrm{PP}}=21.4 \mathrm{~Hz}\right), 4.02\left(\mathrm{~d},{ }^{2} J_{\mathrm{PP}}=21.4\right.$ $\mathrm{Hz}$ ) with relative intensities 9:1, respectively. ${ }^{31} \mathrm{P}\left\{{ }^{1} \mathrm{H}\right\} \mathrm{NMR}$ in $\mathrm{DMF}(\delta)$ : two $\mathrm{AB}$ multiplets at $5.07\left(\mathrm{~d},{ }^{2} J_{\mathrm{PP}}=22.3 \mathrm{~Hz},{ }^{1} J_{\mathrm{PPt}}=\right.$ $4015 \mathrm{~Hz}), 4.51\left(\mathrm{~d},{ }^{2} J_{\mathrm{PP}}=22.3 \mathrm{~Hz},{ }^{1} J_{\mathrm{PPt}}=3488 \mathrm{~Hz}\right), 5.02\left(\mathrm{~d},{ }^{2} J_{\mathrm{PP}}\right.$ $\left.=21.4,{ }^{1} J_{\mathrm{PPt}}=4015 \mathrm{~Hz}\right), 4.48\left(\mathrm{~d},{ }^{2} J_{\mathrm{PP}}=21.4 \mathrm{~Hz},{ }^{1} J_{\mathrm{PPt}}=3488\right.$ $\mathrm{Hz}$ ) with relative intensities $1: 1$, respectively. The same synthesis, carried out in $\mathrm{CH}_{2} \mathrm{Cl}_{2}$, followed by precipitation with $\mathrm{Et}_{2} \mathrm{O}$ affords 2a, with a yield of $70 \% .{ }^{1} \mathrm{H} \mathrm{NMR}$ in $\mathrm{CD}_{2} \mathrm{Cl}_{2}(\delta): 9.47$ (br s, $1 \mathrm{H}$, $\mathrm{NH}_{2}$ ), 7.71-7.28 (c m, 30H, $\mathrm{PPh}_{3}$ ), 7.12 (br s, $\left.1 \mathrm{H}, \mathrm{NH}_{2}\right), 6.81$ (d, $\left.{ }^{3} J_{\mathrm{HH}}=7.0 \mathrm{~Hz}, 1 \mathrm{H}, \mathrm{H6}\right], 5.85\left[\mathrm{~d},{ }^{3} J_{\mathrm{HH}}=7.0 \mathrm{~Hz}, 1 \mathrm{H}, \mathrm{H} 5\right], 3.20(\mathrm{~s}$, $\left.3 \mathrm{H}, \mathrm{NCH}_{3}\right) .{ }^{31} \mathrm{P}\left\{{ }^{1} \mathrm{H}\right\} \mathrm{NMR}$ in $\mathrm{CD}_{2} \mathrm{Cl}_{2}(\delta)$ : AB multiplet at $5.11(\mathrm{~d}$, $\left.{ }^{2} J_{\mathrm{PP}}=21.3 \mathrm{~Hz},{ }^{1} J_{\mathrm{PPt}}=3939 \mathrm{~Hz}\right), 3.58\left(\mathrm{~d},{ }^{2} J_{\mathrm{PP}}=21.3 \mathrm{~Hz},{ }^{1} J_{\mathrm{PPt}}=\right.$ $3455 \mathrm{~Hz}) .{ }^{195} \mathrm{Pt} \mathrm{NMR}(\delta)$ in $\mathrm{CH}_{2} \mathrm{Cl}_{2}:-4163\left(\mathrm{dd},{ }^{1} J_{\mathrm{PPt}}=3430\right.$ and $3960 \mathrm{~Hz}$ ). Crystals for X-ray analysis, having the composition $\mathbf{2 a} \cdot 3 \mathrm{DMF}$, were obtained from a DMF solution of $\mathbf{2 a}$ by slow diffusion of diethyl ether vapors, at room temperature.

Synthesis of cis-[( $\left.\left.\mathrm{PPh}_{3}\right)_{2} \mathrm{Pt}(9-\mathrm{MeGu})\left(\mathrm{ONO}_{2}\right)\right]\left(\mathrm{NO}_{3}\right) \cdot 2 \mathrm{DMF}$ (3a). By using the procedure of $\mathbf{2 a}$, complex $\mathbf{3 a}$ was isolated with a yield of $55 \%$. Diffusion of $\mathrm{Et}_{2} \mathrm{O}$ into a DMF solution afforded colorless crystals having the composition cis- $\left(\mathrm{PPh}_{3}\right)_{2} \mathrm{Pt}(9-\mathrm{MeGu})$ $\left(\mathrm{NO}_{3}\right)_{2} \cdot 2 \mathrm{DMF}$. Elem anal. Calcd for $\mathrm{C}_{42} \mathrm{H}_{37} \mathrm{~N}_{8} \mathrm{O}_{8} \mathrm{P}_{2} \mathrm{Pt}$ : C, 48.56; H, 3.60; N, 10.78. Found: C, 48.91; H, 3.72; N, 10.31. ${ }^{1} \mathrm{H}$ NMR in DMSO- $_{6}(\delta): 11.5$ (br s, $\left.1 \mathrm{H}, \mathrm{N} 1 \mathrm{H}\right), 8.66(\mathrm{~s}, 1 \mathrm{H}, \mathrm{H} 8), 7.6-7.3(\mathrm{c}$ m, 30H, $\mathrm{PPh}_{3}$ ), 6.95 (br s, $2 \mathrm{H}, \mathrm{NH}_{2}$ ), 3.38 (s, 3H, $\mathrm{NCH}_{3}$ ). DMF resonances: $7.94(\mathrm{~s}, 1 \mathrm{H}, \mathrm{CHO}), 2.88\left(\mathrm{~s}, 3 \mathrm{H}, \mathrm{CH}_{3}\right), 2.72(\mathrm{~s}, 3 \mathrm{H}$, $\left.\mathrm{CH}_{3}\right) .{ }^{31} \mathrm{P}\left\{{ }^{1} \mathrm{H}\right\} \mathrm{NMR}$ in DMSO- $d_{6}(\delta)$ : AB multiplets at $7.94(\mathrm{~d}$, $\left.{ }^{2} J_{\mathrm{PP}}=22.6 \mathrm{~Hz},{ }^{1} J_{\mathrm{PPt}}=3482 \mathrm{~Hz}\right), 5.12\left(\mathrm{~d},{ }^{2} J_{\mathrm{PP}}=22.6 \mathrm{~Hz},{ }^{1} J_{\mathrm{PPt}}=\right.$ $4048 \mathrm{~Hz}) .{ }^{31} \mathrm{P}\left\{{ }^{1} \mathrm{H}\right\}$ NMR in DMF $(\delta)$ : two AB multiplets at 7.12 $\left(\mathrm{d},{ }^{2} J_{\mathrm{PP}}=22.6 \mathrm{~Hz},{ }^{1} J_{\mathrm{PPt}}=3465 \mathrm{~Hz}\right), 4.99\left(\mathrm{~d},{ }^{2} J_{\mathrm{PP}}=22.6 \mathrm{~Hz},{ }^{1} J_{\mathrm{PPt}}\right.$ $=4032 \mathrm{~Hz}), 5.71\left(\mathrm{~d},{ }^{2} J_{\mathrm{PP}}=22.6 \mathrm{~Hz},{ }^{1} J_{\mathrm{PPt}}=3465 \mathrm{~Hz}\right), 4.92(\mathrm{~d}$, $\left.{ }^{2} J_{\mathrm{PP}}=22.6 \mathrm{~Hz},{ }^{1} J_{\mathrm{PPt}}=4032 \mathrm{~Hz}\right)$. There were minor resonances at 5.73 and 5.46 ppm (apparent singlets). 3a is insoluble in chlorinated solvents. Crystals for X-ray analysis, having the composition $\mathbf{3 a} \cdot 2 \mathrm{DMF}$, were obtained from a DMF solution of $\mathbf{3 a}$ by slow diffusion of diethyl ether vapors, at room temperature.

Synthesis of cis-[( $\left.\left.\mathrm{PPh}_{3}\right)_{2} \mathbf{P t}(\mathbf{1 - M e C y})_{2}\right]\left(\mathrm{NO}_{3}\right)_{2}$ (4a). To a solution of cis-[( $\left.\left(\mathrm{PPh}_{3}\right)_{2} \mathrm{Pt}\left(\mathrm{NO}_{3}\right)_{2}\right] \cdot \mathrm{DMF}(35.3 \mathrm{mg}, 0.04 \mathrm{mmol})$ in $\mathrm{CH}_{2} \mathrm{Cl}_{2}$ $(2.5 \mathrm{~mL})$ was added $9.8 \mathrm{mg}$ of $1-\mathrm{MeCy}(0.08 \mathrm{mmol})$, and the suspension was stirred at room temperature for $17 \mathrm{~h}$. The resulting solid was recovered by filtration, washed with pentane, and dried under vacuum. The product was purified by dissolution in DMF and precipitated with $\mathrm{Et}_{2} \mathrm{O}$. The yield of $\mathbf{4 a}$ was $28.9 \mathrm{mg}(68 \%)$. Elem anal. Calcd for $\mathrm{C}_{46} \mathrm{H}_{44} \mathrm{~N}_{8} \mathrm{O}_{8} \mathrm{P}_{2} \mathrm{Pt}$ : C, 50.50; H, 4.05; N, 10.24. Found: C, 50.56; H, 4.48; N, 10.49. ${ }^{1} \mathrm{H}$ NMR in DMSO- $d_{6}(\delta)$ : 9.04 (br s, $1 \mathrm{H}, \mathrm{NH}_{2}$ ), 7.93 (br s, $1 \mathrm{H}, \mathrm{NH}_{2}$ ), 7.6-7.3 (c m, 16H, $\mathrm{PPh}_{3}$ and H6), $5.78\left(\mathrm{~d},{ }^{3} \mathrm{~J}_{\mathrm{HH}}=7.3 \mathrm{~Hz}, 1 \mathrm{H}, \mathrm{H} 5\right), 2.91\left(\mathrm{~s}, 3 \mathrm{H}, \mathrm{NCH}_{3}\right)$. ${ }^{31} \mathrm{P}\left\{{ }^{1} \mathrm{H}\right\} \mathrm{NMR}$ in DMSO- $d_{6}(\delta):-0.81\left(\mathrm{~s},{ }^{1} J_{\mathrm{PPt}}=3525 \mathrm{~Hz}\right) .{ }^{195} \mathrm{Pt}$ $\mathrm{NMR}$ in $\mathrm{CH}_{2} \mathrm{Cl}_{2}(\delta):-4198\left(\mathrm{~s},{ }^{1} J_{\mathrm{PPt}}=3540 \mathrm{~Hz}\right)$.

Synthesis of cis-[(PMePh $\left.)_{2} \mathbf{P t}(\mathbf{1 - M e C y})_{2}\right]\left(\mathrm{NO}_{3}\right)_{2}$ (4b). A solution of cis- $\left(\mathrm{PMePh}_{2}\right)_{2} \mathrm{Pt}\left(\mathrm{ONO}_{2}\right)_{2}(80.8 \mathrm{mg}, 0.11 \mathrm{mmol})$ and $28 \mathrm{mg}$ of $1-\mathrm{MeCy}(0.22 \mathrm{mmol})$ in $\mathrm{DMF}(4 \mathrm{~mL})$ was stirred at room temperature for $1 \mathrm{~h}$. The addition of $\mathrm{Et}_{2} \mathrm{O}(25 \mathrm{~mL})$ afforded a powdered solid, which was recovered by filtration, washed with ether, and dried under vacuum. The product was purified by dissolution in DMF and precipitated with $\mathrm{Et}_{2} \mathrm{O}$. The yield of cis$\left[\left(\mathrm{PMePh}_{2}\right)_{2} \mathrm{Pt}(1-\mathrm{MeCy})_{2}\right]\left(\mathrm{NO}_{3}\right)_{2}$ was $69 \mathrm{mg}(65 \%)$. Elem anal. Calcd for $\mathrm{C}_{36} \mathrm{H}_{40} \mathrm{~N}_{8} \mathrm{O}_{8} \mathrm{P}_{2} \mathrm{Pt}$ : C, 44.59; H, 4.17; N, 11.55. Found: C, 44.34; $\mathrm{H}, 4.48 ; \mathrm{N}, 11.80 .{ }^{1} \mathrm{H}$ NMR in DMSO- $d_{6}(\delta): 8.88\left(\mathrm{br} \mathrm{s}, 1 \mathrm{H}, \mathrm{NH}_{2}\right)$, 7.97 (br s, $1 \mathrm{H}, \mathrm{NH}_{2}$ ), 7.6-7.3 (c m, 10H, PMePh $), 7.35$ (d, ${ }^{3} J_{\mathrm{HH}}$ $=7.2 \mathrm{~Hz}, 1 \mathrm{H}, \mathrm{H} 6), 5.55\left(\mathrm{~d},{ }^{3} J_{\mathrm{HH}}=7.1 \mathrm{~Hz}, 1 \mathrm{H}, \mathrm{H} 5\right), 3.06(\mathrm{~s}, 3 \mathrm{H}$, $\left.\mathrm{NCH}_{3}\right), 1.89\left(\mathrm{~d},{ }^{2} J_{\mathrm{HP}}=9.2 \mathrm{~Hz}, 3 \mathrm{H}, \mathrm{PMePh}{ }_{2}\right) .{ }^{31} \mathrm{P}\left\{{ }^{1} \mathrm{H}\right\} \mathrm{NMR}$ in 
Montagner et al.

Table 1. Crystallographic Data and Details of Structure Refinements for Compounds $\mathbf{1 a}-\mathbf{3 a}, \mathbf{4 b}$, and $\mathbf{5 b}$

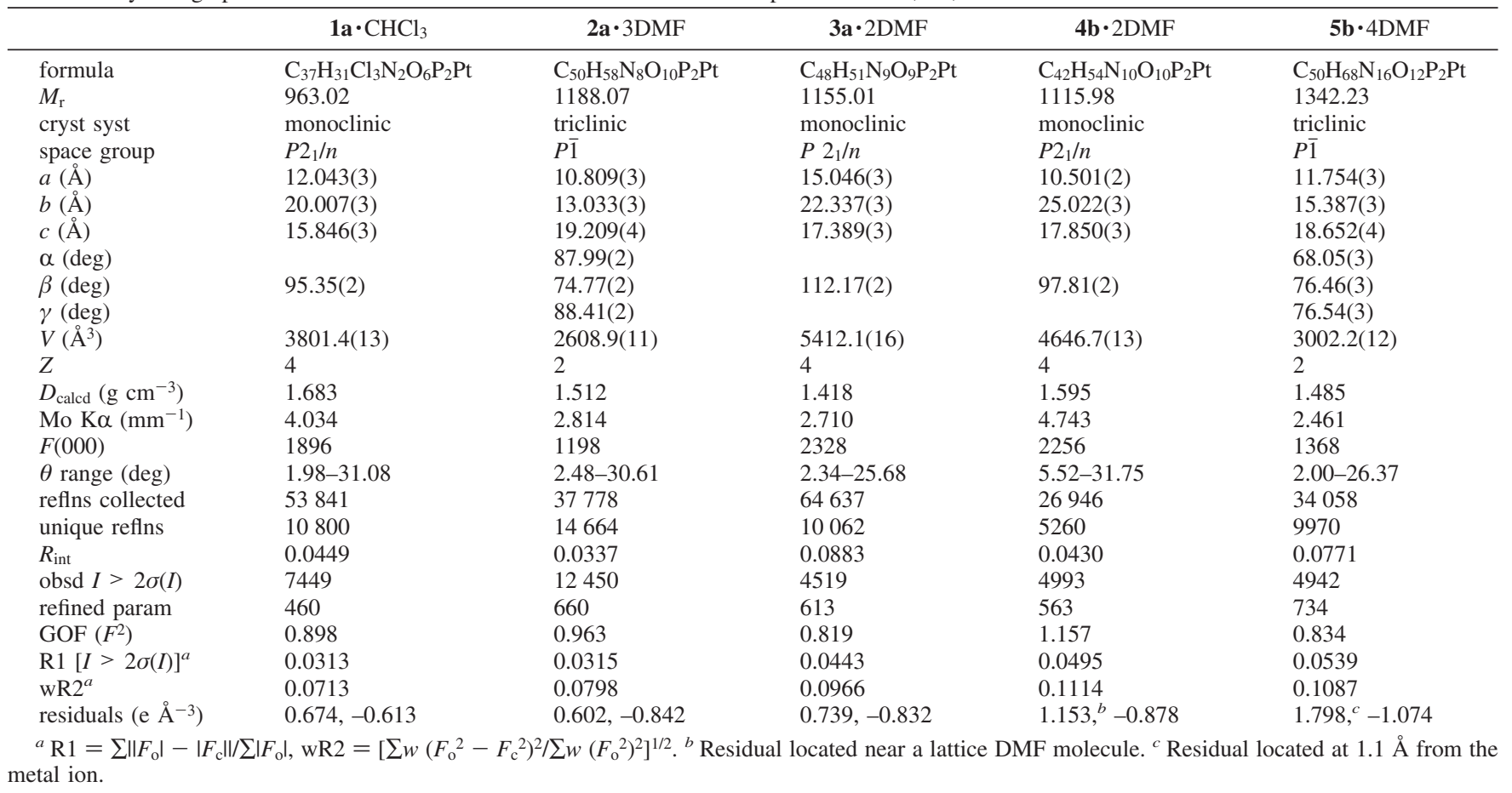

DMSO- $d_{6}(\delta):-11.13\left(\mathrm{~s},{ }^{1} J_{\mathrm{PPt}}=3322 \mathrm{~Hz}\right)$. Crystals for X-ray analysis, analyzed as $\mathbf{4 b} \cdot 2 \mathrm{DMF}$ (by NMR), were obtained by slow diffusion of $\mathrm{Et}_{2} \mathrm{O}$ vapors into a DMF solution of $\mathbf{4 b}$.

Synthesis of cis-[(PPh $\left.)_{2} \mathbf{P t}(\mathbf{9}-\mathrm{MeGu})_{2}\right]\left(\mathrm{NO}_{3}\right)_{2}$ (5a). To a solution of $c i s-\left[\left(\mathrm{PPh}_{3}\right)_{2} \mathrm{Pt}\left(\mathrm{ONO}_{2}\right)_{2}\right] \cdot \mathrm{DMF}(50.9 \mathrm{mg}, 0.06 \mathrm{mmol})$ in 3 $\mathrm{mL}$ of $\mathrm{CH}_{2} \mathrm{Cl}_{2}$ was added $18.6 \mathrm{mg}$ of $9-\mathrm{MeGu}(0.12 \mathrm{mmol})$, and the suspension was stirred at room temperature for $36 \mathrm{~h}$. The resulting white solid was recovered by filtration, washed with $\mathrm{CH}_{2} \mathrm{Cl}_{2}$, and dried under vacuum. The sample was purified from $\mathrm{DMF} / \mathrm{Et}_{2} \mathrm{O}$. The yield of $\mathbf{5 a}$ was $55 \mathrm{mg}(84 \%)$. Elem anal. Calcd for $\mathrm{C}_{48} \mathrm{H}_{44} \mathrm{~N}_{10} \mathrm{O}_{8} \mathrm{P}_{2} \mathrm{Pt}$ : C, 49.10; H, 3.78; N, 14.32. Found: C, 48.73; $\mathrm{H}, 3.71 ; \mathrm{N}, 14.29 .{ }^{1} \mathrm{H}$ NMR in DMSO- $d_{6}(\delta): 11.3($ br s, $1 \mathrm{H}, \mathrm{N} 1 \mathrm{H})$, 7.74 (s, 1H, H8), 7.6-7.3 (c m, 15H, $\mathrm{PPh}_{3}$ ), 6.81 (br s, 2H, $\mathrm{NH}_{2}$ ), $3.27\left(\mathrm{~s}, 3 \mathrm{H}, \mathrm{NCH}_{3}\right) .{ }^{31} \mathrm{P}\left\{{ }^{1} \mathrm{H}\right\} \mathrm{NMR}$ in DMSO- $d_{6}(\delta): 1.54\left(\mathrm{~s},{ }^{1} J_{\mathrm{PPt}}\right.$ $=3507 \mathrm{~Hz}$ ). ${ }^{15} \mathrm{~N}$ NMR (inverse detected) in DMSO- $d_{6}(\delta):-203$ (N7), -216 (N9), -226 (N1H), -297 (N2H $)$.

Synthesis of cis-[( $\left.\left.\mathrm{PMePh}_{2}\right)_{2} \mathbf{P t}(\mathbf{9}-\mathrm{MeGu})_{2}\right]\left(\mathrm{NO}_{3}\right)_{2}(\mathbf{5 b})$. With the procedure reported for $\mathbf{5 a}, \mathbf{5 b}$ was prepared with a yield of $67 \%$ from $1 \mathbf{b}(102 \mathrm{mg}, 0.14 \mathrm{mmol})$ and $9-\mathrm{MeGu}(46 \mathrm{mg}, 0.28 \mathrm{mmol})$ in $\mathrm{CH}_{2} \mathrm{Cl}_{2}(10 \mathrm{~mL})$. Elem anal. Calcd for $\mathrm{C}_{38} \mathrm{H}_{40} \mathrm{~N}_{12} \mathrm{O}_{8} \mathrm{P}_{2} \mathrm{Pt}$ : C, 43.48; $\mathrm{H}, 3.85 ; \mathrm{N}, 16.00$. Found: $\mathrm{C}, 43.52 ; \mathrm{H}, 4.46 ; \mathrm{N}, 15.97 .{ }^{1} \mathrm{H}$ NMR in DMSO- $d_{6}(\delta): 11.16$ (br s, 1H, N1H), 7.87 (s, 1H, H8), 7.7-7.1 (c m, 10H, PMePh $), 6.84$ (br s, $2 \mathrm{H}, \mathrm{NH}_{2}$ ), 3.28 (s, 3H, $\mathrm{NCH}_{3}$ ), 1.93 $\left(\mathrm{d},{ }^{2} J_{\mathrm{HP}}=8.7 \mathrm{~Hz}, 3 \mathrm{H}, \mathrm{PMePh}\right) \cdot{ }^{31} \mathrm{P}\left\{{ }^{1} \mathrm{H}\right\} \mathrm{NMR}$ in DMSO- $d_{6}(\delta)$ : $-9.21\left(\mathrm{~s},{ }^{1} J_{\mathrm{PPt}}=3341 \mathrm{~Hz}\right) .{ }^{15} \mathrm{~N}$ NMR (inverse detected) in DMSO$d_{6}(\delta):-198(\mathrm{~N} 7),-216(\mathrm{~N} 9),-227(\mathrm{~N} 1 \mathrm{H}),-297\left(\mathrm{~N}_{2} \mathrm{H}_{2}\right)$. Crystals for X-ray analysis were obtained by slow diffusion of $\mathrm{Et}_{2} \mathrm{O}$ vapors into a DMF solution of $\mathbf{5 b}$.

X-ray Structure Determinations. Crystal data and details of structural refinements are reported in Table 1.

Diffraction data for compounds $\mathbf{1 a}-\mathbf{3 a}$ and $\mathbf{5 b}$ were collected on a Nonius DIP-1030H system equipped with Mo $\mathrm{K} \alpha$ radiation $(\lambda=0.71073 \AA)$ at ambient temperature, except the data collection of $\mathbf{2 a}$, which was performed at $T=200$ (2) K. Because of the small crystal dimensions (approximately $0.15 \times 0.14 \times 0.10 \mathrm{~mm}$ ), the intensity data of $\mathbf{4 b}$ were measured at the RX diffraction beamline of Elettra Synchrotron, Trieste, Italy [CCD MarResearch detector, $\lambda=1.00000 \AA, T=100(2) \mathrm{K}]$. Cell refinement, indexing, and scaling of all of the data sets were carried out using Denzo ${ }^{9}$ and Scalepack. ${ }^{9}$ All of the structures were solved by direct methods and subsequent difference Fourier analyses ${ }^{10}$ and refined by the full-matrix least-squares method based on $F^{2}$ with all observed reflections. ${ }^{10}$ Besides the nitrate anions, the difference Fourier maps revealed that some solvent residuals successfully interpreted as chloroform in $\mathbf{1 a}$ and dimethylformamide in $\mathbf{2 a}, \mathbf{3 a}, \mathbf{4 b}$, and $\mathbf{5 b}$, accounting for three, two, two, and four molecules for metal units, respectively; some of these were found to be disordered over two positions. All hydrogen atoms were located at geometrical positions, except those of disordered solvent molecules; those of cytosine exocyclic amino groups in $\mathbf{2 a}$ and $\mathbf{5 a}$ were derived from the difference Fourier map. The crystal packing of both compounds evidence about $30 \%$ of the unit cell accessible to the solvent, and three lattice DMF molecules per complex unit in 2a (two in 3a) were detected on the difference Fourier map and successfully refined. The volume left out in the crystal by the complexes and nitrate anions accounts for about 22 and $38 \%$ of the unit cell in $\mathbf{4 b}$ and $\mathbf{5 b}$, and two and four solvent DMF molecules (per complex unit), respectively, occupy this area. All of the calculations were performed using the WinGX system, version $1.70 .05 .{ }^{11}$

\section{Results and Discussion}

1. Structural Characterization of 1a. The removal of the chloride ligands in cis- $\left[\left(\mathrm{PPh}_{3}\right)_{2} \mathrm{PtCl}_{2}\right]$, using $\mathrm{AgNO}_{3}$, leads to the dinitrato complex $\mathbf{1 a}$ and its crystallization in $\mathrm{DMF}$, in the presence of diethyl ether vapors, or in $\mathrm{CHCl}_{3}$ affords crystals having the composition $\mathbf{1 a} \cdot \mathrm{DMF}$ or $\mathbf{1 a} \cdot \mathrm{CHCl}_{\mathbf{3}}$,

(9) Otwinowski, Z.; Minor, W. Processing of X-ray Diffraction Data Collected in Oscillation Mode. In Methods in Enzymology; Carter, C. W., Jr., Sweet, R. M., Eds.; Academic Press: New York, 1997; Vol. 276, p 307.

(10) Sheldrick, G. M. SHELX97, Programs for Crystal Structure Analysis, release 97-2; University of Göttingen: Göttingen, Germany, 1998.

(11) Farrugia, L. J. J. Appl. Crystallogr. 1999, 32, 837. 


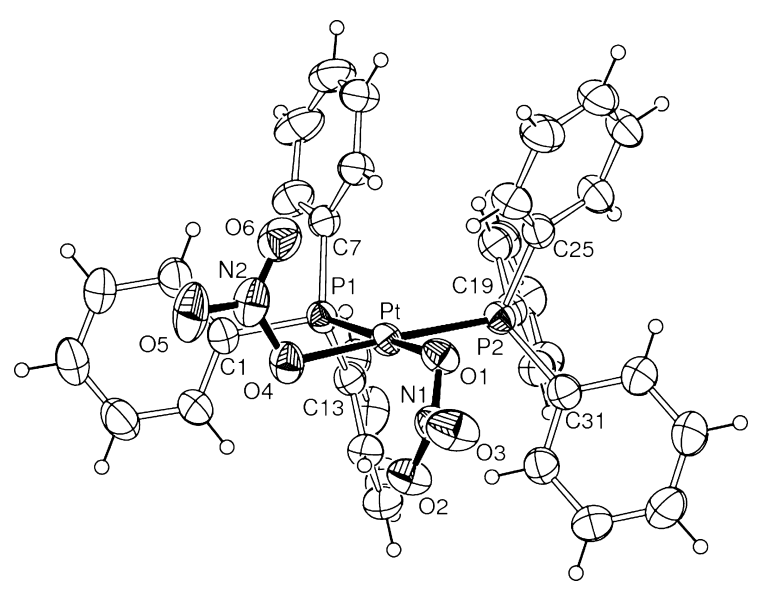

Figure 1. ORTEP drawing of complex 1a (only ipso-carbon atoms are labeled for clarity). Selected bond lengths $(\AA)$ and angles (deg): $\mathrm{Pt}-\mathrm{O} 1$ 2.093(2), $\mathrm{Pt}-\mathrm{O} 4$ 2.105(3), Pt-P1 2.239(1), Pt-P2 2.248(1); O1-Pt-O4 84.70(10), O1-Pt-P1 174.61(7), O4-Pt-P1 90.89(8), O1-Pt-P2 87.44(8), O4-Pt-P2 172.14(7), P1-Pt-P2 96.97(4), N1-O1-Pt1 113.8(6), N2-O4-Pt1 115.6(7).

respectively. The X-ray structure of $\mathbf{1 a} \cdot \mathrm{CHCl}_{3}$ reveals one independent complex cocrystallized with a molecule of chloroform.

Figure 1 reports the ORTEP drawing of the metal complex. The platinum displays a distorted square coordination, bound to the $\mathrm{P}$ donors and $\mathrm{O}$ nitrate atoms, in a cis configuration. The nitrato groups are directed on opposite sides with respect to the coordination plane, and their mean planes form dihedral angles of $69.1(1)$ and $84.9(1)^{\circ}$ with it. No significant displacement of the metal from the $\mathrm{P}_{2} \mathrm{O}_{2}$ plane is detected, and the donor atoms are coplanar within $\pm 0.03 \AA$. Phenyl rings $\mathrm{C} 13$ and $\mathrm{C} 19$ are involved in $\pi-\pi$ stacking interaction [centroid-to-centroid distance of 3.644(2) ̊̊], but no intermolecular phenyl interaction is detected in the crystal. The coordination bond lengths and angles, as well as the orientation of nitrate anions, are very similar to those detected in the $\mathrm{PMePh}_{2},{ }^{3} \mathrm{PMe}_{3},{ }^{12}$ and $\mathrm{PEt}_{3}{ }^{13}$ derivatives. This last feature, however, contrasts with that found in the analogue cis- $\left(\mathrm{NH}_{3}\right)_{2} \mathrm{Pt}\left(\mathrm{ONO}_{2}\right)_{2}$, in which the nitrate groups lie on the same side of the ligand plane. ${ }^{14}$

In a solution of coordinating solvents, 1a undergoes an extensive solvolysis of the $\mathrm{Pt}-\mathrm{O}$ bonds, with the formation of complexes in which one or both of the $\mathrm{NO}_{3}{ }^{-}$ligands are replaced by solvent molecules. The process is clearly evidenced by ${ }^{31} \mathrm{P}$ NMR spectroscopy, as is illustrated in Figure 2.

In $\mathrm{CDCl}_{3}$ at $27{ }^{\circ} \mathrm{C}$ (Figure 2a), the ${ }^{31} \mathrm{P}\left\{{ }^{1} \mathrm{H}\right\}$ NMR spectrum of 1a exhibits a sharp singlet at $\delta 3.35$ ppm flanked by ${ }^{195} \mathrm{Pt}$ NMR satellites $\left({ }^{1} J_{\mathrm{PPt}}=4018 \mathrm{~Hz}\right.$ ), while in DMSO- $d_{6}$ (Figure $2 \mathrm{~b})$, the signal is broad and shifted at lower field $(\delta 4.6 \mathrm{ppm}$, with ${ }^{1} J_{\mathrm{PPt}}=$ ca. $4070 \mathrm{~Hz}$ ), indicative of chemical exchange between the $\mathrm{NO}_{3}{ }^{-}$ligands and the solvent molecules. Figure $2 \mathrm{c}$ shows the spectrum of a freshly prepared solution of $\mathbf{1 a}$ in DMF- $d_{7}$ (ca. $0.1 \mathrm{M}$ ), characterized by two broad reso-

(12) Suzuki, Y.; Miyamoto, T. K.; Ichida, H. Acta Crystallogr., Sect. C 1993, 49, 1318.

(13) Kuehl, C. J.; Tabellion, F. M.; Arif, A. M.; Stang, P. J. Organometallics 2001, 20, 1956.

(14) Lippert, B.; Lock, C. J. L.; Rosemberg, B.; Zvagulis, M. Inorg. Chem. 1977, 16, 1525.

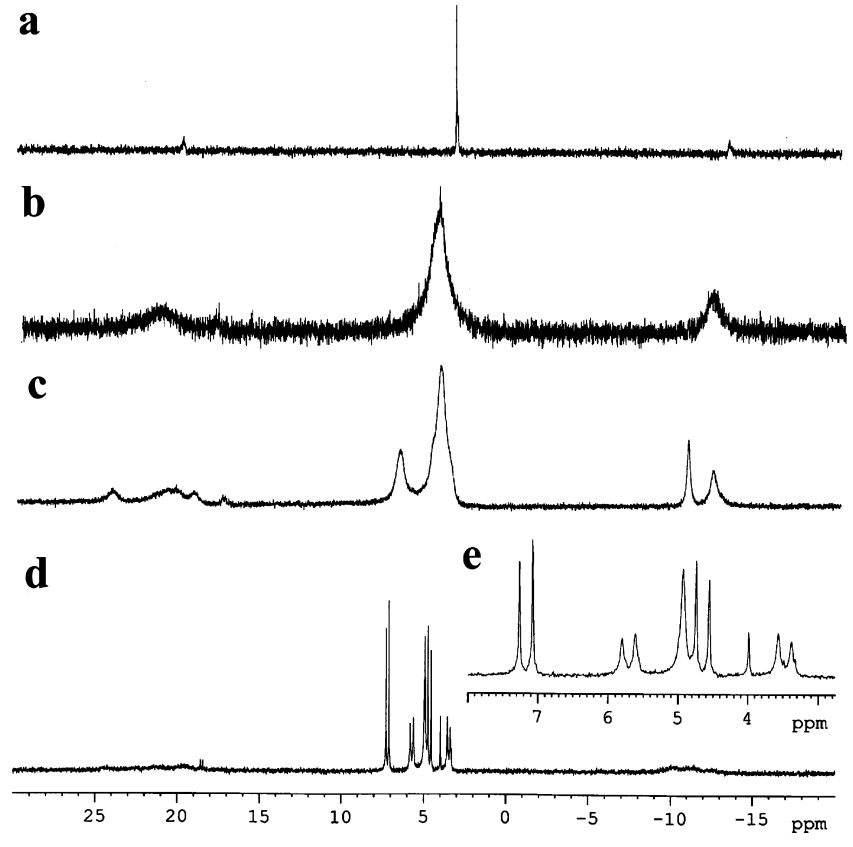

Figure 2. ${ }^{31} \mathrm{P}\left\{{ }^{1} \mathrm{H}\right\}$ NMR spectra $(0.1 \mathrm{M})$ of $\mathbf{1 a}$ in (a) $\mathrm{CDCl}_{3}$, (b) DMSO$d_{6}$, (c) DMF- $d_{7}\left(25^{\circ} \mathrm{C}\right)$, and (d) DMF- $d_{7}\left(-60{ }^{\circ} \mathrm{C}\right)$ and (e) an expansion of part d.

nances (at $\delta 6.68$ and $4.28 \mathrm{ppm}$, with ${ }^{1} J_{\mathrm{PPt}}$ values in the range $4050-4260 \mathrm{~Hz}$ ), which does not change after some hours at room temperature. When the solution is cooled at $-60{ }^{\circ} \mathrm{C}$ (Figure 2d), the spectrum shows two $\mathrm{AB}$ multiplets, one sharp (at $\delta 7.15$ and $4.7 \mathrm{ppm},{ }^{2} J_{\mathrm{PP}}=22.9 \mathrm{~Hz}$, relative intensity 39\%) and the second (at $\delta 5.7$ and $3.5 \mathrm{ppm},{ }^{2} J_{\mathrm{PP}}=$ $23.3 \mathrm{~Hz}$ ) less intense (27\%) and broader. Both of them are consistent with the presence of monosubstituted species of the type cis- $\left[\left(\mathrm{PPh}_{3}\right)_{2} \mathrm{Pt}\left(\mathrm{ONO}_{2}\right)(\mathrm{DMF})\right]^{+}$, in which the $\mathrm{NO}_{3}{ }^{-}$ group behaves as a monodentate ligand, and/or as a bridging ligand, in polynuclear species. The remaining resonances (Figure 2e) at $\delta 4.93$ (slightly broad singlet, relative intensity $26 \%$ ) and $\delta 3.99 \mathrm{ppm}$ (singlet, relative intensity 8\%) are tentatively attributed to the species $c i s-\left[\left(\mathrm{PPh}_{3}\right)_{2} \mathrm{Pt}(\mathrm{DMF})_{2}\right]^{2+}$ and unsolvated species $c i s-\left(\mathrm{PPh}_{3}\right)_{2} \mathrm{Pt}\left(\mathrm{ONO}_{2}\right)_{2}$. The absence of resolved ${ }^{195} \mathrm{Pt}$ satellites (at $-60{ }^{\circ} \mathrm{C}$ ) precludes a deeper insight into the nature of species in equilibrium.

2. X-ray Structures of cis-[(PPh$)_{2} \mathbf{P t}$ (nucleobase)$\left.\left(\mathrm{ONO}_{2}\right)\right]^{+}$(nucleobase $\left.=1-\mathrm{MeCy}, 2 \mathrm{a} ; 9-\mathrm{MeGu}, 3 \mathrm{a}\right)$ and cis- $\left[\left(\mathbf{P M e P h}_{2}\right)_{2} \mathbf{P t}(\text { nucleobase })_{2}\right]^{2+}$ (nucleobase $=1-\mathrm{MeCy}$, $\mathbf{4 b} ; \mathbf{9 - M e G u , ~ 5 b ) . ~ T h e ~ a d d i t i o n ~ o f ~} 1$ equiv of $1-\mathrm{MeCy}$ to a DMF solution of 1a, followed by condensation of diethyl ether vapors, afforded crystals having the composition 2a.3DMF, as established by ${ }^{1} \mathrm{H}$ NMR and X-ray structure determination. Similarly, with 9-MeGu the analogue complex $3 \mathbf{3} \cdot 2 \mathrm{DMF}$ has been isolated in good yield. In the presence of 2 equiv of nucleobase, the bisadducts $4 \mathbf{4}$ and $\mathbf{5 a}$ are formed in quantitative yield (by NMR).

The monoadduct complexes 2a and 3a, reported in Figures 3 and 4, present close similarities not only in the conformation but also in the crystal packing and will be discussed together.

The Pt ion exhibits a square-planar coordination sphere achieved through the phosphorus atoms, the nitrogen donor from the nucleobase, and the nitrate oxygen atom. The 
Montagner et al.

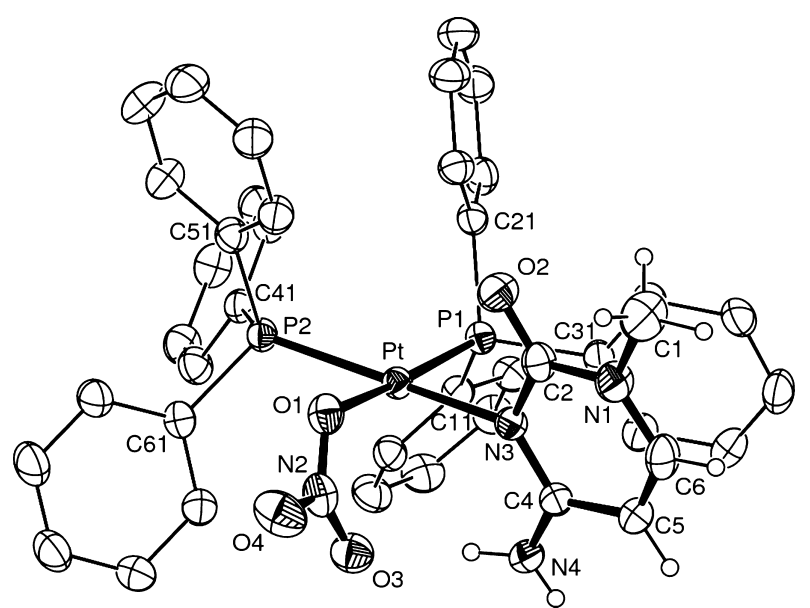

Figure 3. ORTEP drawing (35\% probability ellipsoid) of the complex cation of 2a. Only ipso-carbon atoms are labeled for the sake of clarity.

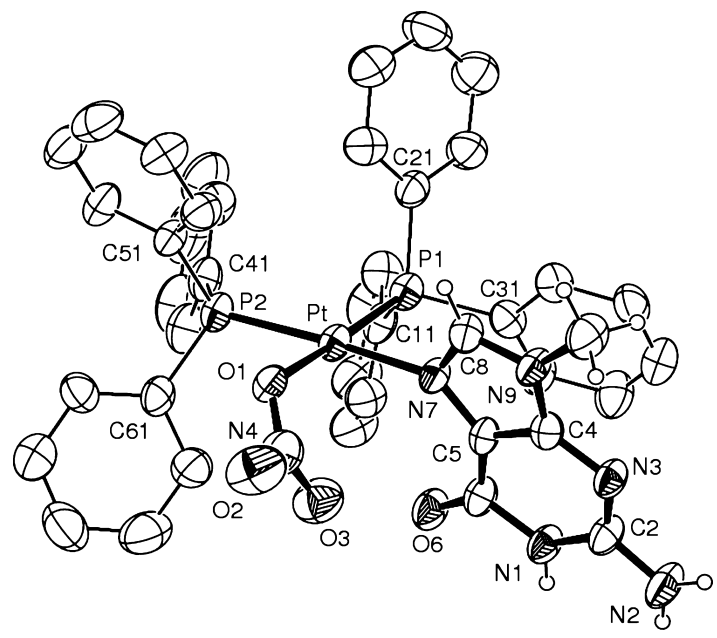

Figure 4. ORTEP drawing (35\% probability ellipsoid) of the complex cation of 3a. Only ipso-carbon atoms are labeled for the sake of clarity.

nucleobase is bound to the metal through $\mathrm{N} 3$ of $1-\mathrm{MeCy}$ and $\mathrm{N} 7$ of $9-\mathrm{MeGu}$, which represent the preferential binding sites for pyrimidine and purine bases, respectively. The bond distances and angles are reported in Table 2 and do not show any anomaly. The $\mathrm{Pt}-\mathrm{N} 3$ bond distance in 2a [2.101(2) $\mathrm{A}]$ is slightly longer than the corresponding distance $\mathrm{Pt}-\mathrm{N} 7$ in 3a $[2.075(5) \AA]$ and can be ascribed to the endocyclic $\mathrm{C}-\mathrm{N}_{\mathrm{d}}-\mathrm{C}$ angle $\left(\mathrm{N}_{\mathrm{d}}\right.$ being the donor site), narrower in the five-membered ring than in the six-membered ring, which allows a closer approach of the ligand to the metal center.

Both of the bases have an unsymmetrical coordination; in fact, the $\mathrm{C} 2-\mathrm{N} 3-\mathrm{Pt}$ angle of the cytosine (on the side of the exocyclic amino group) and the $\mathrm{C} 5-\mathrm{N} 7-\mathrm{Pt}$ one of the guanine (carbonyl group side) are larger by ca. $12^{\circ}$ and ca. $7^{\circ}$ than the $\mathrm{C} 4-\mathrm{N} 3-\mathrm{Pt}$ and $\mathrm{C} 8-\mathrm{N} 7-\mathrm{Pt}$ angles, respectively. As far as $\mathrm{Pt}-\mathrm{P}$ bond lengths are concerned, it is worth noting the shorter value measured for the phosphine trans to the nitrate anion, and the narrower $\mathrm{N}-\mathrm{Pt}-\mathrm{O} 1$ angle [86.39(10) and $86.9(2)^{\circ}$ in $\mathbf{2 a}$ and $\mathbf{3 a}$, respectively] in comparison to the $\mathrm{P} 1-\mathrm{Pt}-\mathrm{P} 2$ one [98.83(3) and $98.08(7)^{\circ}$ ], likely induced by steric requirements.

The 1-MeCy and 9-MeGu bases are oriented almost normal to the coordination mean plane, forming a close comparable angle with the latter of ca. $76^{\circ}$ in both complexes.
Table 2. Coordination Bond Lengths $(\AA)$ and Angles (deg) and Geometrical Parameters for 2a and $\mathbf{3 a}$

\begin{tabular}{lcc}
\hline & 2a & 3a \\
\hline $\mathrm{Pt}-\mathrm{N} 3 / 7^{a}$ & $2.100(2)$ & $2.075(5)$ \\
$\mathrm{Pt}-\mathrm{O} 1$ & $2.117(2)$ & $2.140(5)$ \\
$\mathrm{Pt}-\mathrm{P} 1$ & $2.2508(9)$ & $2.247(2)$ \\
$\mathrm{Pt}-\mathrm{P} 2$ & $2.2846(9)$ & $2.2780(18)$ \\
& & \\
$\mathrm{N} 3 / 7-\mathrm{Pt}-\mathrm{O} 1$ & $86.37(10)$ & $86.9(2)$ \\
$\mathrm{N} 3 / 7-\mathrm{Pt}-\mathrm{P} 1$ & $90.81(7)$ & $90.38(17)$ \\
$\mathrm{N} 3 / 7-\mathrm{Pt}-\mathrm{P} 2$ & $169.08(7)$ & $171.40(17)$ \\
$\mathrm{O} 1-\mathrm{Pt}-\mathrm{P} 1$ & $173.61(7)$ & $173.88(15)$ \\
$\mathrm{O} 1-\mathrm{Pt}-\mathrm{P} 2$ & $83.53(7)$ & $84.51(13)$ \\
$\mathrm{P} 1-\mathrm{Pt}-\mathrm{P} 2$ & $98.82(3)$ & $98.08(7)$ \\
$\mathrm{N} 2-\mathrm{O} 1-\mathrm{Pt}$ & $116.37(18)$ & \\
$\mathrm{C} 2-\mathrm{N} 3-\mathrm{Pt}$ & $112.92(19)$ & \\
$\mathrm{C} 4-\mathrm{N} 3-\mathrm{Pt}$ & $124.9(2)$ & \\
$\mathrm{N} 4-\mathrm{O} 1-\mathrm{Pt}$ & & $117.9(5)$ \\
$\mathrm{C} 5-\mathrm{N} 7-\mathrm{Pt}$ & & $130.0(5)$ \\
$\mathrm{C} 8-\mathrm{N} 7-\mathrm{Pt}$ & & $123.0(5)$ \\
base/coord plane $\mathrm{NOP}_{2}$ (deg) & $76.38(8)$ & $76.91(9)$ \\
$\mathrm{NO}_{3} / \mathrm{coord}$ plane $\mathrm{NOP}_{2}$ (deg) & $68.3(1)$ & $61.7(2)$ \\
${ }^{a} \mathrm{~N} 3$ refers to 2a and $\mathrm{N} 7$ to $3 \mathbf{3 a}$. & & \\
& &
\end{tabular}

On the other hand, the nitrate group is more bent, and the mean plane figures out a dihedral angle of $65^{\circ}$ (mean value for the two structures), with nitrate oxygen $\mathrm{O} 3$ pointing toward the cytosine exocyclic amino group N4 in 2a (at a hydrogen-bond distance from the latter, O3-N4 = 2.99 $\AA$ ) and toward the guanine carboxyl oxygen in $\mathbf{3 a}(\mathrm{O} 3-\mathrm{O} 6=$ $3.09 \AA$ ). In both complexes, the phosphine phenyl group C31 is oriented in such a way as to favor an intramolecular $\pi-\pi$ interaction with the model nucleobase (centroid-to-centroid distance of ca. $3.5 \AA$ ). Moreover, an intramolecular stacking interaction is detected in 3a between phenyl rings $\mathrm{C} 11$ with $\mathrm{C} 41$ [distance between centroids $=3.587(7) \AA$ ] . The corresponding distance in 2a is slightly longer [4.007(2) $\AA$ ], indicating a different, although small, difference in the conformations of the phosphine ligands.

Whereas we were unable to grow crystals of $\mathbf{4 a}$ and $\mathbf{5 a}$ for X-ray analyses, this was possible for the $\mathrm{PMePh}_{2}$ analogues, $\mathbf{4 b}$ and $\mathbf{5 b}$, easily prepared from $\mathbf{1 b}$ in the presence of 2 equiv of $1-\mathrm{MeCy}$ and $9-\mathrm{MeGu}$, respectively. The X-ray structural analysis of $\mathbf{4 b}$ and $\mathbf{5 b}$ confirms the formation of the bisadducts species cis-[( $\left(\mathrm{PMePh}_{2}\right)_{2} \mathrm{Pt}(1-$ $\left.\mathrm{MeCy})_{2}\right]^{2+}$ and cis- $\left[\left(\mathrm{PMePh}_{2}\right)_{2} \mathrm{Pt}(9-\mathrm{MeGu})_{2}\right]^{2+}$, and an ORTEP view of these complexes, showing similar geometrical features, are illustrated in Figures 5 and 6, while the structural data are collected in Table 3.

The bases, bound through $\mathrm{N} 3$ and N7 in $\mathbf{4 b}$ and $\mathbf{5 b}$, respectively, assume a head-to-tail arrangement that is the most frequent orientation of two bases in a square-planar geometry. ${ }^{15}$ The $\mathrm{Pt}-\mathrm{N}$ and $\mathrm{Pt}-\mathrm{P}$ coordination bond lengths follow a trend as observed in the monoadduct complexes. The $\mathrm{C} 4-\mathrm{N} 3-\mathrm{Pt}$ and $\mathrm{C} 8-\mathrm{N} 7-\mathrm{Pt}$ angles in $\mathbf{4 b}$ and $\mathbf{5 b}$ are significantly larger than the $\mathrm{C} 2-\mathrm{N} 3-\mathrm{Pt}$ and $\mathrm{C} 5-\mathrm{N} 7-\mathrm{Pt}$ ones, respectively, confirming an unsymmetrical coordination of the bases (Table 3). Coordination $\mathrm{Pt}-\mathrm{N}$ distances compare well with those found in the correspondent $\mathrm{PMe}_{3}$ deriva-

(15) Zangrando, E.; Pichierri, F.; Randaccio, L.; Lippert, B. Coord. Chem. Rev. 1996, 156, 275. 


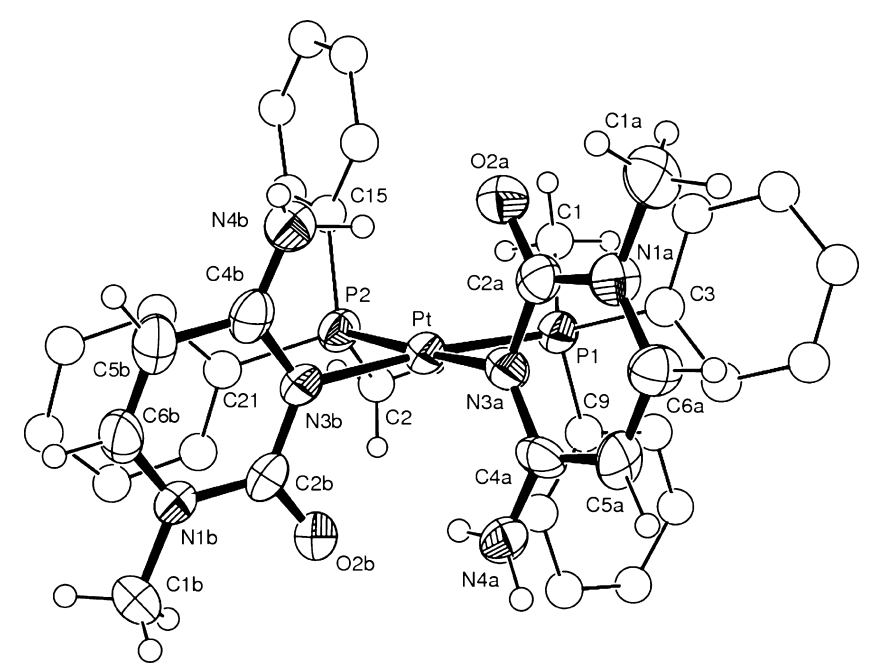

Figure 5. ORTEP drawing (35\% probability ellipsoid) of the complex cation of $\mathbf{4 b}$. Phosphine carbon atoms as spheres of the fixed radius are labeled for the sake of clarity.

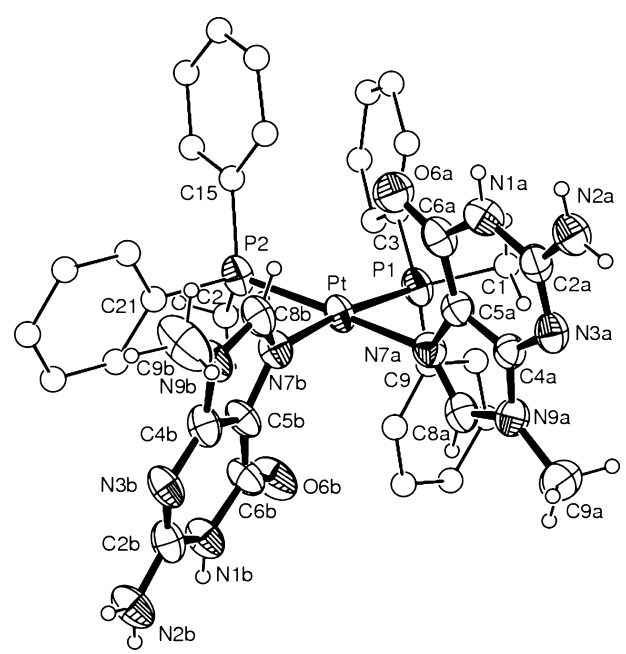

Figure 6. ORTEP drawing (35\% probability ellipsoid) of the complex cation of $\mathbf{5 b}$.

tives, ${ }^{16,17}$ although the structural characterization of the cis$\left[\left(\mathrm{PMe}_{3}\right)_{2} \mathrm{Pt}(9-\mathrm{MeGu})_{2}\right]^{2+}$ species ${ }^{17}$ is less accurate. The $\mathrm{Pt}-\mathrm{P}$ bond distances appear only slightly longer in the present complexes containing the bulkier $\mathrm{PMePh}_{2}$ (2.270 and 2.262 $\AA$ mean values in $\mathbf{4 b}$ and $\mathbf{5 b}$, respectively) when compared with the average values of 2.255 and $2.250 \AA$ of the $\mathrm{PMe}_{3}$ complexes.

The complex $\mathbf{4 b}$ presents a pseudo-2-fold symmetry in the solid state for the conformation assumed by the $\mathrm{PMePh}_{2}$ ligands (methyl groups on different sides of the coordination plane) and a head-to-tail arrangement of the bases. This allows the formation of intermolecular hydrogen bonds between each exocyclic $\mathrm{NH}_{2}$ group and the carbonyl of the

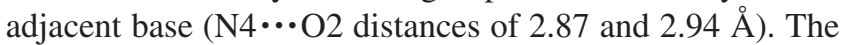
other $\mathrm{NH}_{2}$ hydrogen atom of each cytosine forms a hydrogen bond with a nitrate anion $(\mathrm{N} 4-\mathrm{H} \cdots \mathrm{O}$ of $2.85 \AA$, mean distance). Intramolecular $\pi-\pi$ interactions occur between

(16) Trovò, G.; Valle, G.; Longato, B. J. Chem. Soc., Dalton Trans. 1993, 669.

(17) Longato, B.; Bandoli, G.; Trovò, G.; Marasciulo, E.; Valle, G. Inorg. Chem. 1995, 34, 1745.
Table 3. Coordination Bond Lengths $(\AA)$ and Angles (deg) and Geometrical Parameters for $\mathbf{4 b}$ and $\mathbf{5 b}$

\begin{tabular}{lcc}
\hline & $\mathbf{4 b}$ & $\mathbf{5 b}$ \\
\hline $\mathrm{Pt}-\mathrm{N} 3 \mathrm{a} / 7 \mathrm{a}^{a}$ & $2.106(7)$ & $2.087(7)$ \\
$\mathrm{Pt}-\mathrm{N} 3 \mathrm{~b} / 7 \mathrm{~b}$ & $2.095(8)$ & $2.082(7)$ \\
$\mathrm{Pt}-\mathrm{P} 1$ & $2.265(2)$ & $2.268(3)$ \\
$\mathrm{Pt}-\mathrm{P} 2$ & $2.275(2)$ & $2.256(3)$ \\
& & \\
$\mathrm{N} 3 \mathrm{a}-\mathrm{Pt}-\mathrm{N} 3 \mathrm{~b}$ & $86.3(3)$ & \\
$\mathrm{N} 7 \mathrm{a}-\mathrm{Pt}-\mathrm{N} 7 \mathrm{~b}$ & & \\
$\mathrm{~N} 3 \mathrm{a} / 7 \mathrm{a}-\mathrm{Pt}-\mathrm{P} 1$ & $89.5(2)$ & $89.7(3)$ \\
$\mathrm{N} 3 \mathrm{~b} / 7 \mathrm{~b}-\mathrm{Pt}-\mathrm{P} 1$ & $174.3(2)$ & $172.9(2)$ \\
$\mathrm{N} 3 \mathrm{a} / 7 \mathrm{a}-\mathrm{Pt}-\mathrm{P} 2$ & $176.1(2)$ & $174.7(2)$ \\
$\mathrm{N} 3 \mathrm{~b} / 7 \mathrm{~b}-\mathrm{Pt}-\mathrm{P} 2$ & $91.5(2)$ & $90.2(2)$ \\
$\mathrm{P} 1-\mathrm{Pt}-\mathrm{P} 2$ & $92.88(9)$ & $95.91(9)$ \\
$\mathrm{C} 2 \mathrm{a}-\mathrm{N} 3 \mathrm{a}-\mathrm{Pt}$ & $113.4(6)$ & \\
$\mathrm{C} 4 \mathrm{a}-\mathrm{N} 3 \mathrm{a}-\mathrm{Pt}$ & $125.2(6)$ & \\
$\mathrm{C} 2 \mathrm{~b}-\mathrm{N} 3 \mathrm{~b}-\mathrm{Pt}$ & $114.4(7)$ & \\
$\mathrm{C} 4 \mathrm{~b}-\mathrm{N} 3 \mathrm{~b}-\mathrm{Pt}$ & $123.1(6)$ & \\
$\mathrm{C} 5 \mathrm{a}-\mathrm{N} 7 \mathrm{a}-\mathrm{Pt}$ & & \\
$\mathrm{C} 8 \mathrm{a}-\mathrm{N} 7 \mathrm{a}-\mathrm{Pt}$ & & $121.5(6)$ \\
$\mathrm{C} 5 \mathrm{~b}-\mathrm{N} 7 \mathrm{~b}-\mathrm{Pt}$ & & $131.1(6)$ \\
$\mathrm{C} 8 \mathrm{~b}-\mathrm{N} 7 \mathrm{~b}-\mathrm{Pt}$ & & $123.7(6)$ \\
$\mathrm{base} \mathrm{a} /$ coord plane $\mathrm{N}_{2} \mathrm{P}_{2}$ (deg) & $80.6(2)$ & $79.5(1)$ \\
base b/coord plane $\mathrm{N}_{2} \mathrm{P}_{2}$ (deg) & $79.8(2)$ & $86.25(1)$ \\
base a/base b (deg) & $77.7(2)$ & $76.99(1)$ \\
a $\mathrm{N} 3 \mathrm{a}, \mathrm{b}$ refers to 4b and N7a,b to 5b. & & \\
& &
\end{tabular}

each base ring and a phenyl group [base a-phenyl C3, centroid-to-centroid distance 3.480(6) Å; base b-phenyl C21, $3.448(7) \AA]$. In $\mathbf{5 b}$, the intramolecular $\pi-\pi$ interaction between the imidazole ring of base $b$ and phenyl $\mathrm{C} 21$ is even present [centroid-to-centroid distance 3.488(7) ̊]. On the other hand, the different conformation assumed by the phosphine P1, leading the methyl group $\mathrm{C} 1$ to lay approximately in the coordination plane (Figure 6), induces a weaker $\pi-\pi$ stacking linking the phenyl groups $\mathrm{C} 3$ and $\mathrm{C} 15$ [distance 3.784(7) $\AA$ ]. In the solid-state structure, a hydrogenbonding interaction of type $\mathrm{C}-\mathrm{H} \cdots \mathrm{O}$ between a phenyl group and the guanine oxygen $\mathrm{O} 6$ in $\mathbf{3 a}(\mathrm{O} 6 \mathrm{~b}$ in $\mathbf{5 b})$ is also present. The $\mathrm{C} \cdots \mathrm{O}$ distances are 3.361(11) and 3.246(13) $\AA$, respectively. All of these interactions are likely to stabilize the crystal packing and the solid-state conformations of these complexes. It is worth noting the crystal packing of $\mathbf{5 b}$, where each guanine is connected through hydrogen bonds via amino group N2 and nitrogen N3 of the centrosymmetric moiety, forming a mismatched homo base pairing $\left[\mathrm{NH}_{2} \cdots \mathrm{N}=3.03\right.$ $\AA$ (base a) and $2.98 \AA$ (base b)]. ${ }^{18}$ The atoms of the two nucleobases are coplanar within \pm 0.03 and $\pm 0.02 \AA$ in $\mathbf{4 b}$ and $\mathbf{5 b}$ ), respectively. Moreover, N1 and N2 nitrogen atoms act as hydrogen-bond donors toward a nitrate. Figure 7 shows the hydrogen-bonding pattern, which gives rise to a zigzag complex polymer with pendant nitrate anions.

3. NMR Characterization of $c i s-\left[\mathbf{L}_{2} \mathbf{P t}(\right.$ nucleobase)$\left.\left(\mathrm{ONO}_{2}\right)\right]^{+}$and $c i s-\left[\mathrm{L}_{2} \mathbf{P t}(\text { nucleobase })_{2}\right]^{2+}$. In solution, the isolated bisadducts cis- $\left[\mathrm{L}_{2} \mathrm{Pt}(\text { nucleobase })_{2}\right]^{2+}$ do not manifest particular features. The ${ }^{1} \mathrm{H}$ and ${ }^{31} \mathrm{P}$ NMR spectra of the isolated complexes, obtained in different solvents, show a single set of resonances indicative of the chemical equivalence of the two

(18) (a) Roitzsch, M.; Lippert, B. Chem. Commun. 2005, 5991. (b) Freisinger, E.; Rother, I. B.; Lüth, M. S.; Lippert, B. Proc. Natl. Acad. Sci. U.S.A. 2003, 100, 3748. (c) Erxleben, A.; Metzger, S.; Britten, J. F.; Lock, C. J. L.; Albinati, A.; Lippert, B. Inorg. Chim. Acta 2002, $339,461$. 


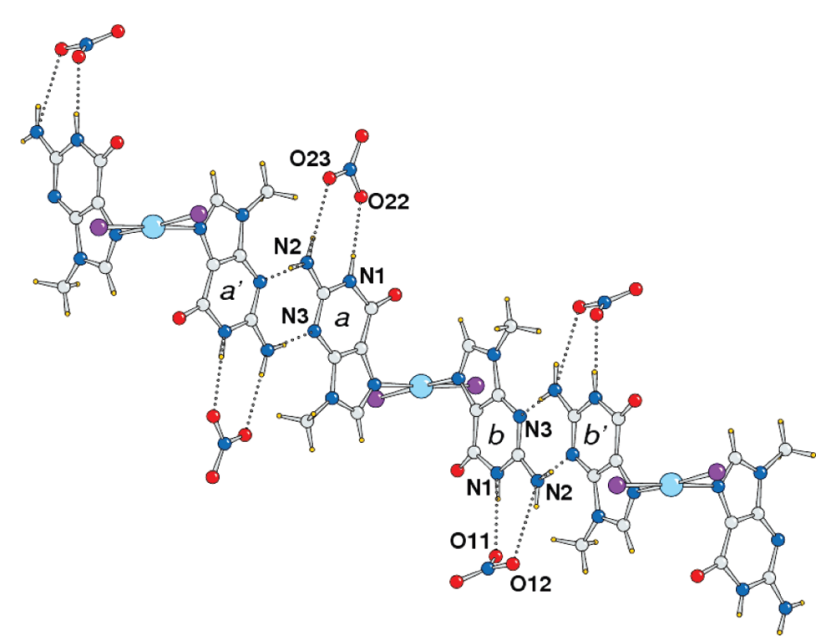

Figure 7. Crystal packing of $\mathbf{5 b}$ showing the one-dimensional polymers built by hydrogen-bond interactions (dotted lines).

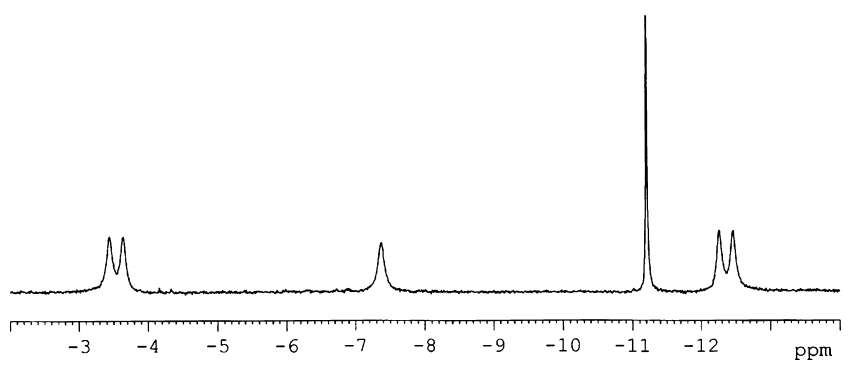

Figure 8. ${ }^{31} \mathrm{P}\left\{{ }^{1} \mathrm{H}\right\}$ NMR spectra in DMSO- $d_{6}$ (central part) of a mixture $(0.1 \mathrm{M})$ of $\mathbf{1 b}$ and $\mathbf{4 b}(1: 1)$.

nucleobases. As previously noticed, the platination of the cytosine at the N3 site shifts at lower field the resonance of the exocyclic $\mathrm{NH}_{2}$ protons, observed as broad singlets with the same relative intensities, at $\delta 9.04$ and 7.93 ppm for $\mathrm{L}=\mathrm{PPh}_{3}$, in DMSO- $d_{6}$. Similarly, the platination of 9-MeGu at the N7 site, as confirmed through ${ }^{1} \mathrm{H}-{ }^{15} \mathrm{~N}$ heterocorrelated spectra (see the Supporting Information), causes deshielding of the H1 proton, up to $0.8 \mathrm{ppm}$ for $\mathbf{5 a}$.

The coordination of two nucleobases to cis $-\mathrm{L}_{2} \mathrm{Pt}\left(\mathrm{ONO}_{2}\right)_{2}$ (in DMSO- $d_{6}$ ) determines an upfield shift of the ${ }^{31} \mathrm{P}$ NMR resonances and a decrease of the ${ }^{1} J_{\mathrm{PPt}}$ values. For $1-\mathrm{MeCy}$, the chemical shift differences $(\Delta \delta)$ are 4.3 and $5.4 \mathrm{ppm}$ for $\mathrm{PMePh}_{2}$ and $\mathrm{PPh}_{3}$, respectively, while for $9-\mathrm{MeGu} \Delta \delta$ are 2.4 and $3.1 \mathrm{ppm}$. As an example of the spectroscopic changes observed upon coordination of $1-\mathrm{MeCy}$ to $\mathrm{cis}$ $\left(\mathrm{PMePh}_{2}\right)_{2} \mathrm{Pt}\left(\mathrm{ONO}_{2}\right)_{2}$, the ${ }^{31} \mathrm{P}$ NMR spectrum obtained immediately after dissolution of equimolar amounts of dinitrate and 1-MeCy, in DMSO- $d_{6}$ [or, alternatively, cis$\left(\mathrm{PMePh}_{2}\right)_{2} \mathrm{Pt}\left(\mathrm{ONO}_{2}\right)_{2}$ and cis- $\left[\left(\mathrm{PMePh}_{2}\right)_{2} \mathrm{Pt}(1-\mathrm{MeCy})_{2}\right]\left(\mathrm{NO}_{3}\right)_{2}$ in a 1:1 molar ratio] is shown in Figure 8.

The spectrum is characterized by two AX doublets $\left({ }^{2} J_{\mathrm{PP}}\right.$ $=24.3 \mathrm{~Hz}$ ) with the same relative intensity, at $\delta-12.36$ $\operatorname{ppm}\left({ }^{1} J_{\mathrm{PPt}}=3934 \mathrm{~Hz}\right)$ and $\delta-3.54 \mathrm{ppm}\left({ }^{1} J_{\mathrm{PPt}}=3453 \mathrm{~Hz}\right)$, attributed to the monoadduct $c i s-\left[\left(\mathrm{PMePh}_{2}\right)_{2} \mathrm{Pt}(1-\mathrm{MeCy})\right]^{2+}$, a broad singlet at $\delta-6.90 \mathrm{ppm}$ of unreacted $\mathbf{1 b}$, and a sharp singlet at $\delta-11.13 \mathrm{ppm}\left({ }^{1} J_{\mathrm{PPt}}=3322 \mathrm{~Hz}\right)$ due to the bisadduct $\mathbf{4 b}$. This last signal is the only detectable one when an additional equiv of nucleobase is added, while the initial AX multiplet disappears immediately. The doublet at lower

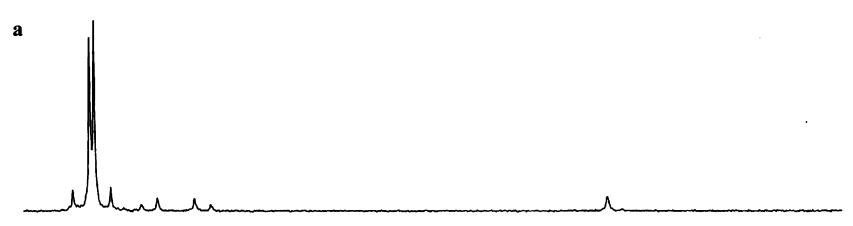

b

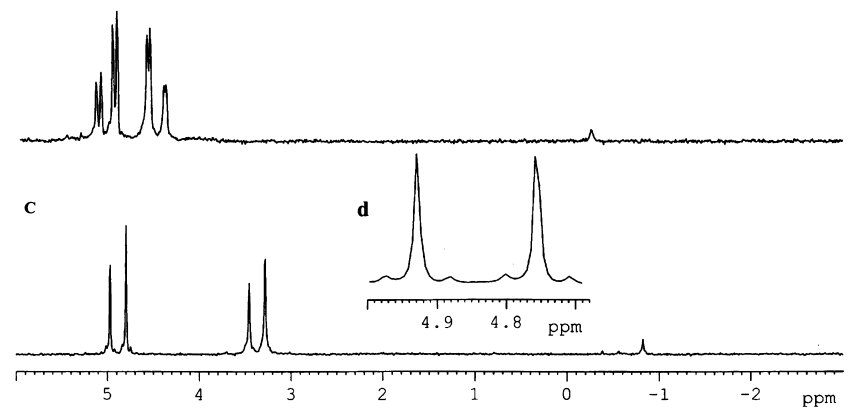

Figure 9. ${ }^{31} \mathrm{P}\left\{{ }^{1} \mathrm{H}\right\}$ NMR spectra (central part) of $\mathbf{2 a}$ in (a) DMSO- $d_{6}$, (b) DMF- $d_{7}$, and (c) $\mathrm{CD}_{2} \mathrm{Cl}_{2}$ and (d) an expansion of part $\mathrm{c}$.

field in Figure 8, having ${ }^{1} J_{\mathrm{PPt}}=3934 \mathrm{~Hz}$, can be assigned to the phosphine trans to the nitrate ligand or, more likely, to a solvent molecule. The upfield doublet, with ${ }^{1} J_{\mathrm{PPt}}=3453$ $\mathrm{Hz}$, consequently is attributable to the phosphine trans to the nucleobase. Similar results were obtained with $9-\mathrm{MeGu}$ (in DMSO- $d_{6}: \delta-11.46\left({ }^{1} J_{\mathrm{PPt}}=3870 \mathrm{~Hz}\right),-2.72\left({ }^{1} J_{\mathrm{PPt}}=\right.$ $3430 \mathrm{~Hz}$, with ${ }^{2} J_{\mathrm{PP}}=23.4 \mathrm{~Hz}$ ).

For both of the nucleobases investigated, the monoadducts cis- $\left[\mathrm{L}_{2} \mathrm{Pt}(\text { nucleobase })\right]^{2+}\left(\mathrm{L}=\mathrm{PMePh}_{2}\right)$ are in equilibrium with relatively high concentrations of the bisadducts cis$\left[\mathrm{L}_{2} \mathrm{Pt}(\text { nucleobase })_{2}\right]^{2+}$ (and dinitrate). Thus, from the relative intensities of the signals in Figure 8, cis-[( $\left.\mathrm{PMePh}_{2}\right)_{2} \mathrm{Pt}(1-$ $\mathrm{MeCy})]^{2+}$ accounts for $63 \%$ of all of the phosphinecontaining species. However, when $\mathrm{L}$ is $\mathrm{PPh}_{3}$, the relative stability of the monoadducts $\mathbf{2 a}$ and $\mathbf{3 a}$ appears largely increased. In Figure 9a, the ${ }^{31} \mathrm{P}$ NMR spectrum of a solution of ca. $0.1 \mathrm{M}$ of $\mathbf{2 a}$ in the DMSO- $d_{6}$ is shown. The bisadduct $\mathbf{4 a}$, in equilibrium with the monoadduct, is observed as a singlet at $\delta-0.81 \mathrm{ppm}$ and its relative intensity is about $4 \%$. The resonance due to cis- $\left(\mathrm{PPh}_{3}\right)_{2} \mathrm{Pt}\left(\mathrm{NO}_{3}\right)_{2}$ is undetectable, being overlapped with those of the monoadduct, characterized by two $\mathrm{AB}$ multiplets.

The main resonances, at $\delta 5.36\left({ }^{1} J_{\mathrm{PPt}}=4080 \mathrm{~Hz}\right)$ and $5.12\left({ }^{1} J_{\mathrm{PPt}}=3536 \mathrm{~Hz}\right)$, with ${ }^{2} J_{\mathrm{PP}}=22.3 \mathrm{~Hz}$, can be assigned to the solvent complex cis-[( $\left.\left.\mathrm{PPh}_{3}\right)_{2} \mathrm{Pt}(1-\mathrm{MeCy})(\mathrm{DMSO})\right]^{2+}$, while the weaker multiplets $\delta 4.60$ and $4.02\left({ }^{2} J_{\mathrm{PP}}=21.4\right.$ $\mathrm{Hz})$ are attributable to the species cis-[( $\left(\mathrm{PPh}_{3}\right)_{2} \mathrm{Pt}(1-\mathrm{MeCy}-$ )$\left.\left(\mathrm{ONO}_{2}\right)\right]^{+}$in which the nitrate ion is in the coordination sphere of the metal, as found in the solid-state structure. The intensities of these latter signals, in fact, increase when the $\mathrm{NO}_{3}{ }^{-}$ions are added (such as the $\mathrm{Ph}_{4} \mathrm{AsNO}_{3}$ salt). The unusually small chemical shift differences of the two phosphines $(\Delta \delta=0.24$ and $0.58 \mathrm{ppm})$, compared with that found for the $\mathrm{PMePh}_{2}$ analogue ( $\Delta \delta=8.82 \mathrm{ppm}$; Figure 8), can be accounted for by the presence of strong intraligand $\pi-\pi$ interactions, as are found in the solid state, which prevent the free rotation around the $\mathrm{Pt}-\mathrm{P}$ and/or $\mathrm{Pt}-\mathrm{N} 3$ bonds. The imposed rigidity causes a strong chemical shift 
anisotropy and a consequent shift at lower field of one of the phosphine resonances. ${ }^{19}$

Similar considerations apply to the ${ }^{31} \mathrm{P}$ NMR spectrum of 2a in DMF. As shown in Figure 9b, two AB multiplets have almost the same relative intensity and very similar chemical shifts (see the Experimental Section). These data suggest the presence of the solvent complex cis-[( $\left.\mathrm{PPh}_{3}\right)_{2} \mathrm{Pt}(1-\mathrm{MeCy})-$ $(\mathrm{DMF})]^{2+}$ in which the DMF and the nucleobase are arranged in different conformations on the coordination plane of the metal. The resonances at lower field, having higher values of ${ }^{1} J_{\mathrm{PPt}}(4015 \mathrm{~Hz})$, are assigned to the $\mathrm{PPh}_{3}$ trans to the DMF ligand.

A different pattern of the ${ }^{31} \mathrm{P}$ NMR spectrum is observed in chlorinated solvents. Figure $9 \mathrm{c}$ refers to a solution of $\mathbf{1 a}$ and 1-MeCy (ca. a 1:1.1 molar ratio) in $\mathrm{CD}_{2} \mathrm{Cl}_{2}$. In addition to the singlets at $\delta-0.61$ and +3.49 ppm, due to species $4 \mathbf{a}$ and 1a, respectively, the spectrum is characterized by two AX doublets $\left({ }^{2} J_{\mathrm{PP}}=21.3 \mathrm{~Hz}\right)$ at $\delta 5.11\left({ }^{1} J_{\mathrm{PPt}}=3939 \mathrm{~Hz}\right)$ and $3.58 \mathrm{ppm}\left({ }^{1} J_{\mathrm{PPt}}=3455 \mathrm{~Hz}\right)$ having slightly different line widths. The doublet at higher field, on the basis of its lower value of ${ }^{1} J_{\mathrm{PPt}}$, is assigned to the phosphine trans to the N3-coordinated cytosine. This signal is overlapped with the singlet due to unreacted 1a. The resonance centered at $\delta$ $5.11 \mathrm{ppm}$ exhibits a ${ }^{1} J_{\mathrm{PPt}}$ value $(3939 \mathrm{~Hz})$ typical for a phosphine trans to an oxygen donor ligand. Moreover, this doublet is characterized by very weak satellites (separation of ca. $11 \mathrm{~Hz}$; Figure 9d) likely due to long-range ${ }^{31} \mathrm{P}-{ }^{195} \mathrm{Pt}$ coupling. Such satellites, although less resolved, are detectable also for the doublet at higher field and suggest the presence of a polynuclear species in which the neutral nucleobase acts as a bidentate bridging ligand likely through the N3 and $\mathrm{O} 2$ atoms. Attempts to grow crystals of $\mathbf{2 a}$ from chlorinated solvents in order to prove this unusual binding mode were unsuccessful.

Although in the solid state complexes $\mathbf{2 a}$ and $\mathbf{3 a}$ exhibit strong analogies, in solution they disclose important differences. The ${ }^{31} \mathrm{P}$ NMR spectrum of $\mathbf{3 a}$ in DMSO- $d_{6}$ shows a single set of resonances (AB multiplet at $\delta 7.94$ and 5.12 ppm) indicative of a complete solvolysis of the nitrate $\mathrm{Pt}-\mathrm{O}$ bond. Moreover, the multiplicity of signals observed in a DMF solution (see the Experimental Section) points to the presence of other species in equilibrium, in addition to that found in the solid state and the solvent complex, cis$\left[\left(\mathrm{PPh}_{3}\right)_{2} \mathrm{Pt}\left(9-\mathrm{MeGu}-N^{7}\right)(\mathrm{DMF})\right]^{2+}$. The relatively high difference between the two chemical shift values $(\Delta \delta=2.88$ ppm) could be assigned to the chelated complex cis$\left[\left(\mathrm{PPh}_{3}\right)_{2} \mathrm{Pt}\left(9-\mathrm{MeGu}-N^{7} \mathrm{O}^{6}\right)\right]^{2+}$ in which the nucleobase binds the metal through the $\mathrm{N} 7$ and $\mathrm{O} 6$ atoms, a coordination mode

(19) Garrou, P. E. Chem. Rev. 1977, 77, 313. for the 9-substituted guanines unprecedented for platinum(II). The spectroscopic parameters of this species, which is the main component of the equilibrium mixture (ca. 60\%), are similar to those of the species found in DMSO. The addition of 1 equiv of 9-MeGu to the DMF or DMSO solution of $\mathbf{3 a}$ affords the immediate formation of the bisadduct $\mathbf{5 a}$ in quantitative yield (by NMR).

\section{Conclusions}

The coordination of two molecules of $1-\mathrm{MeCy}$ and 9-MeGu to the metal center of $c i s-\mathrm{L}_{2} \mathrm{Pt}\left(\mathrm{ONO}_{2}\right)_{2}(\mathrm{~L}=$ $\left.\mathrm{PPh}_{2} \mathrm{Me}, \mathrm{PPh}_{3}\right)$ appears kinetically facile, as expected for the presence of good leaving groups, such as the $\mathrm{NO}_{3}{ }^{-}$ ligands. The stereochemistry of the bisadducts cis- $\left[\mathrm{L}_{2} \mathrm{Pt}-\right.$ (nucleobase $\left.)_{2}\right]^{2+}\left(\mathrm{L}=\mathrm{PMePh}_{2}\right)$ is that of a head-to-tail arrangement of the two cytosines and guanines, N3- and N7coordinated, respectively. The X-ray structures confirm that the two nucleobases do not determine steric crowding in the metal coordination sphere (the sums of bond angles $\mathrm{P}-\mathrm{Pt}-\mathrm{P}$ and $\mathrm{N}-\mathrm{Pt}-\mathrm{N}$ are $179.2^{\circ}$ and $180.6^{\circ}$ in $\mathbf{4 b}$ and $\mathbf{5 b}$, respectively). Despite the apparent thermodynamic stability of the corresponding $\mathrm{PPh}_{3}$ analogues, we were unable to crystallize the complexes cis- $\left[\left(\mathrm{PPh}_{3}\right)_{2} \mathrm{Pt}(\text { nucleobase })_{2}\right]^{2+}(\mathbf{4 a}$ and $\mathbf{5 a})$, a failure likely related to the higher steric requirements of the $\mathrm{PPh}_{3}$ (cone angles of $145^{\circ}$ and $136^{\circ}$ for $\mathrm{L}=\mathrm{PPh}_{3}$ and $\mathrm{PMePh}_{2}$, respectively). ${ }^{20} \mathrm{It}$ is worth noting that in the strictly related bisadduct cis-[( $\left.\mathrm{PPh}_{3}\right)_{2} \mathrm{Pt}\left(1-\mathrm{MeCy}-N^{3}\right)(1-\mathrm{MeCy}(-\mathrm{H})-$ $\left.\left.N^{4}\right)\right] \mathrm{NO}_{3}$, containing a neutral and a $\mathrm{NH}_{2}$-deprotonated cytosine, the $\mathrm{P}-\mathrm{Pt}-\mathrm{P}$ and $\mathrm{N} 3-\mathrm{Pt}-\mathrm{N} 4$ angles are $98.22(4)^{\circ}$ and $87.51(13)^{\circ}$, respectively. ${ }^{6}$ The platination of both cytosines at the N3 atom (or the guanine at N7) was expected to further increase such deviations from the ideal value of $90^{\circ}$.

Finally, the relatively high stability of the monoadducts cis- $\left[\mathrm{L}_{2} \mathrm{Pt}(\text { nucleobase })\right]^{2+}$ when $\mathrm{L}=\mathrm{PPh}_{3}$ ligands can be accounted for by the presence in both complexes of a strong intramolecular $\pi-\pi$ interaction occurring between a phenyl group and the pyrimydinic (or purinic) ring, which leads the $\mathrm{P}-\mathrm{Pt}-\mathrm{N} 3 / 7$ angle to assume a value near to ideality.

Acknowledgment. This work was financially supported by the Ministero dell'Universitá e della Ricerca Scientifica e Tecnologica, PRIN 2004.

Supporting Information Available: Crystallographic data in CIF format for the structures reported in this paper and ${ }^{15} \mathrm{~N}-{ }^{1} \mathrm{H}$ HMBC spectra of $\mathbf{5 a}$ in DMSO- $d_{6}$. This material is available free of charge via the Internet at http://pubs.acs.org.

IC7020319

(20) Tolman, C. A. Chem. Rev. 1981, 81, 229. 